\title{
MAAHANMUUTTAJIEN VUOROVAIKUTUSSUHTEET
}

\section{VUOROVAIKUTUKSEN NÄKÖKULMA SOPEUTUMISPROSESSIIN}

\author{
Lotta Kokkonen, FL
}

Viestintätieteiden laitos, Jvuäskylän yliopisto

\section{TIIVISTELMÄ}

Uuden ja erilaisen elämäntilanteen, kuten uuden kulttuurisen ympäristön, kohtaaminen edellyttää aina tavalla tai toisella uuteen elämäntilanteeseen ja uuteen ympäristöön sopeutumista. Useat tutkijat määrittelevät sopeutumisen prosessiksi, joka aiheutuu erilaisten ihmisten ja ympäristöjen kohtaamisesta ja välittömästä kontaktista (esim. Berry 1997; Liebkind 2000; Redfield, Linton \& Herskovits 1936). Käsitetäänkö prosessi ainoastaan yksipuolisena muutoksiin reagointina, kuten psykologisina muutoksina ja käyttäytymisen muutoksina, vai vuorovaikutuksellisena prosessina, jossa vuorovaikutuksen osapuolet yhdessä luovat merkityksiä muutosten keskellä, riippuu näkökulmasta.

Tässä artikkelissa sopeutumista tarkastellaan vuorovaikutuksen näkökulmasta. Sopeutuminen nähdään vuorovaikutusprosessina, jossa henkilö pyrkii luomaan ja ylläpitämään vuorovaikutussuhteita, jotka tukevat henkilön psyykkistä hyvinvointia ja auttavat häntä toimimaan uudessa tai muuttuneessa ympäristössä. Vaikka vuorovaikutuksen näkökulmasta sopeutuminen nähdään dynaamisena, jatkuvasti muuttuvana prosessina, sopeutumisella, ja siis vuorovaikutussuhteilla, voidaan silti nähdä olevan myös tavoite. Vuorovaikutussuhteiden merkitys ja tavoite on tukea henkilön psyykkistä hyvinvointia ja kykyä toimia uudessa ympäristössä. Vuorovaikutuksen näkökulmasta sopeutumisen tavoite ei kuitenkaan ole staattinen, täysin saavutettavissa oleva tila, vaan näkökulman mukaan sopeutumiselle asetetut tavoitteet muuttuvat tilanteen, 
kontekstin ja kulloisenkin vuorovaikutussuhteen mukaan. Kun sopeutumista tarkastellaan vuorovaikutuksellisena prosessina, oleellisinta ei Kimin $(2001,38)$ mukaan ole itse tavoite, vaan siihen tähtäävän prosessin ymmärtäminen.

Tässä artikkelissa ei niinkään tarkastella psyykkistä hyvinvointia ja kykyä toimia uudessa tai muuttuneessa ympäristössä sinänsä, vaan näitä tavoitteita lähestytään tarkastelemalla sitä, mikä merkitys vuorovaikutussuhteilla uudessa tai muuttuneessa ympäristössä voi olla. Tällöin vuorovaikutussuhteita ei nähdä ainoastaan välineellisesti sopeutumisen tavoitteiden saavuttamisessa, vaan keskeisinä ilmiöinä ja entiteetteinä, joissa annetaan ja vastaanotetaan tukea, vaihdetaan informaatiota ja luodaan merkityksiä.

Asiasanat: sopeutumisprosessi, vuorovaikutussubde

ja morovaikutuksen näkökulma

\section{JOHDANTO}

Sopeutuminen uuteen kulttuuriseen ympäristöön nähdään usein prosessina, joka johtuu erilaisten kulttuuristen traditioiden kohtaamisesta. Kaikenlaiset muutokset elämässä voivat aiheuttaa tilanteita, joihin henkilön on tavalla tai toisella sopeuduttava. Ympäristömme voi muuttua siksi, että itse matkustamme erilaiseen ja uuteen ympäristöön, tai siksi, että ympäristö ympärillämme muuttuu esimerkiksi säätilan muutoksista johtuen, taloudellisen tilanteen muutosten myötä tai uusien tekijöiden ilmestyttyä meille tuttuun ympäristöön. Ympäristön muutos voi olla uusi työpaikka, uusi perheenjäsen, poliittisen tilanteen muuttuminen ympäröivässä yhteiskunnassa, oman taloudellisen tilanteen muuttuminen tai uuteen maahan muuttaminen. Johtuipa muutos elämässämme syystä tai toisesta, useissa tutkimuksissa on todettu, että niin satunnaiset kuin läheisinä pidetyt interpersonaaliset vuorovaikutussuhteet edistävät ihmisten sopeutumista erilaisiin elämänmuutoksiin (esim. 
Eckenrode \& Gore 1981).

Interpersonaalisten vuorovaikutussuhteiden on todettu olevan merkityksellisiä tilanteessa, jossa henkilö muutettuaan maasta toiseen sopeutuu uuteen kulttuuriseen ympäristöön (esim. Berry 1997; Black 1988; Kim 2001; Valtonen 1994; 1998). Vuorovaikutussuhteet nähdään usein yhtenä sopeutumiseen vaikuttavana tekijänä. Suomessa asuvien maahanmuuttajien vuorovaikutussuhteita on käsitelty, tai niitä sivutaan, maahanmuuttajien elinoloja, psyykkistä ja fyysistä hyvinvointia ja työllistymistä käsittelevissä tutkimuksissa (esim. Ahmad 2005; Forsander 2002; Pohjanpää, Paananen \& Nieminen 2003; Sourander 2003). Tähän mennessä on huomattu, että maahanmuuttajien interpersonaaliset vuorovaikutussuhteet ovat tärkeitä maahanmuuttajien sopeutumiskokemuksiin vaikuttavia tekijöitä, mutta itse vuorovaikutussuhteiden problematisointi on jäänyt vähäiseksi.

Tässä artikkelissa tarkastellaan vuorovaikutussuhteiden merkitystä tilanteessa, jossa henkilö on muuttanut maasta toiseen. Ensin on kuitenkin hyvä hahmottaa lyhyesti sitä tutkimuskenttää, johon aihe laajemmin kiinnittyy.

\section{SOPEUTUMINEN UUTEEN TAI} MUUTTUNEESEEN YMPÄRISTÖÖN

Maasta toiseen muuttavien henkilöiden kohtaamat muutokset ovat kiinnostaneet tutkijoita laajalti. Verrattuna muunlaisiin tilanteisiin, kuten uuteen työpaikkaan sopeutumiseen, maasta toiseen ja kulttuurisesta ympäristöstä toiseen muutettaessa ympäristössä tapahtuvat muutokset ovat usein määrällisesti ja laadullisesti hyvin merkittäviä ja merkityksellisiä. Mitä tapahtuu yksilöille tai ryhmille, jotka ovat kehittyneet yhdessä kulttuurisessa kontekstissa ja myöhemmin rakentavat elämäänsä uudessa kulttuurisessa ympäristössä, on kysymys, joka on kiinnostanut tutkijoita esimerkiksi psykologiassa, sosiologiassa, kielitieteissä ja lää- 
ketieteessä. Riippumatta tieteenalasta usein puhutaan sopeutumisesta (adaptation) uuteen kulttuuriseen ympäristöön. Kuitenkin on huomattava, että vaikka, ja ehkä juuri siksi, sopeutumista uuteen kulttuuriseen ympäristöön on tutkittu paljon ja useilla tieteenaloilla, sitä ei ole yksiselitteisesti määritelty tähänastisessa kirjallisuudessa ja tutkimuksissa (Kim 2001, 18-19).

Jo 1930-luvulla antropologit määrittelivät akkulturaatioksi ne ilmiöt ja muutokset, jotka seuraavat eri kulttuureja edustavien ryhmien ja yksilöiden jatkuvasta, välittömästä kontaktista (Redfield, Linton \& Herskovits 1936). Myös nykyisin monet käyttävät termiä aklkulturaatio viitatessaan erilaisten ihmisten ja erilaisten kulttuurien kohtaamisesta aiheutuvaan muutosprosessiin (esim. Berry 1997; Liebkind 2000). Integraatio ja sopeutuminen ovat myös erittäin suosittuja termejä kuvaamaan muutosprosessia erilaisten kulttuurien kohdatessa (Kim 2001; Lepola 2002). Berryn (1997) ja Triandiksen (1997) mukaan uuteen kulttuuriseen ympäristöön sopeutumiseen liittyvä terminologia on kirjavaa, termejä saatetaan käyttää toistensa synonyymeina ja niillä voi tutkijasta riippuen olla hyvinkin erilaiset merkitykset.

Uuteen maahan muuttamisen yhteydessä ajatellaan usein, että sopeutuminen tapahtuu ympäröivään yhteiskuntaan ja sen traditionaalisiin toimintatapoihin, mutta Berryn $(1997,13)$ mukaan sopeutuminen voi tapahtua myös suhteessa tiettyyn etniseen vähemmistöryhmään tai alakulttuuriin. Toisaalta voidaan ajatella, että sopeutuminen on vuorovaikutuksellinen prosessi, jossa osapuolet yhdessä muokkaavat ja luovat sen todellisuuden, jossa elävät, kukin muuttuen tavallaan. Tässä artikkelissa käytetään termiä sopeutuminen, mutta valinnalla ei haluta ottaa kantaa siihen, kenen tulisi erilaisten kulttuuristen traditioiden kohdatessa kyseenalaistaa, saati muuttaa, kulttuurisia arvojaan, asenteitaan tai käyttäytymistapojaan. Sopeutumista voidaan myös tarkastella yksilön tai yhteisön ilmiönä ja tässä artikkelissa sopeutumista tarkastellaan yksilön ja vieraaseen kulttuuriseen ympäristöön muuttavan henkilön eli 
maahanmuuttajan näkökulmasta.

Monet sopeutumisen määritelmät puhuvat muutoksista, joita uuden ympäristön kohtaaminen aiheuttaa (esim. Berry 1997; Searle \& Ward 1990; Ward ym. 1998). Muuttuvaan ympäristöön sopeutumisen tarkastelun lähtökohtana on usein ajatus ihmisen luontaisesta taipumuksesta tavalla tai toisella sopeutua ympäristön muutoksiin (esim. Cohen 1968; Lazarus 1966; Piaget 1963). Tämän kyvyn on jopa nähty olevan edellytyksenä ihmisen evoluutiolle ja ihmiskunnan kehitykselle (Dobuzinskis 1987; Jantsch 1980).

Perinteinen näkemys sopeutumisesta perustuu hyvin pitkälti ajatukseen, että yhdessä kulttuurissa (kulttuuri A) varttunut henkilö muutettuaan toiseen kulttuuriin (kulttuuri B) reagoi tilanteeseen ja uuteen ympäristöön muutoksin, jotka ilmenevät sekä psykologisella että käyttäytymisen tasolla. Uuteen kulttuuriseen ympäristöön sopeutuminen voidaan Wardin (1997) sekä Wardin ja kumppaneiden (esim. Searle \& Ward 1990; Ward, Bochner \& Furnham 2001; Ward \& Kennedy 1992; Ward \& Searle 1991) mukaan jakaa psyykkiseen sopeutumiseen ja sosiokulttuuriseen sopeutumiseen. Myös Berryn $(1997,13)$ mukaan uuden kulttuurin kohtaamisesta aiheutuva sopeutumisprosessi perustuu toisaalta henkilökohtaisen tason psykologisiin ja toisaalta käyttäytymisen muutoksiin.

Psyykkisellä sopeutumisella viitataan usein henkilön psyykkiseen hyvinvointiin ja tyytyväisyyteen. Tällöin sopeutumista ympäristön muutoksiin voidaan tarkastella sisäisenä prosessina, jonka tavoitteena on henkisen hyvinvoinnin ja psyykkisen tasapainon saavuttaminen. Kaikenlaiset muutokset ympäristössä, kuten uuteen maahan muuttaminen, voivat aiheuttaa stressiä ja ahdistusta, jolloin henkinen hyvinvointi ja psyykkinen tasapaino voivat olla uhattuina. Uuteen kulttuuriin sopeutuminen voidaan nähdä ympäristössä tapahtuvien muutosten aiheuttaman hämmennyksen, ahdistuksen ja epävarmuuden hallintana tavalla tai toisella, ja psyykkistä sopeutumista tarkastellaankin usein uuden 
ympäristön kohtaamisesta johtuvan stressin ja selviytymisen puitteissa (Ward 1997, 60). Psyykkinen sopeutuminen riippuu Wardin $(1997,60)$ mukaan henkilön persoonallisuudesta, saatavilla olevasta sosiaalisesta tuesta ja kulloiseenkin muuttuneeseen ympäristöön liittyvistä tekijöistä. Searlen ja Wardin $(1990,450)$ mukaan uuteen kulttuuriseen ympäristöön sopeutuminen on sisäinen, psyykkinen tila, jota pystyy arvioimaan ainoastaan uuden kulttuurisen ympäristön kokenut henkilö itse.

Ympäristön muutokset johtavat Piagetin (1963) mukaan siihen, että ihminen pyrkii reagoimaan muutoksiin toiminnalla, joka johtaa myös kognituivis-affektiivisiin muutoksiin. Tätä toiminnallista puolta sopeutumisessa voidaan tarkastella sosiokulttuurisena sopeutumisena, jolla Wardin $(1997,60)$ mukaan tarkoitetaan uuteen kulttuuriin tulijan kykyä sopeutua joukkoon tai kykyä olla vuorovaikutuksessa ympäröivän kulttuurin edustajien kanssa. Sosiokulttuurinen sopeutuminen on riippuvaista vieraan kulttuurin parissa vietetystä ajasta, aiemmista kulttuurienvälisistä kokemuksista ja vuorovaikutuksesta paikallisten kanssa. (Ward 1996; Ward 1997, 60.) Käytännössä sosiokulttuurinen sopeutuminen nähdään toimintana, jonka kautta tai jonka avulla henkilö oppii uudessa kulttuurisessa ympäristössä soveliaana pidettävän käyttäytymisrepertuaarin (Berry 1997, 13). Tarkastelun kohteena voi olla henkilön kyky olla vuorovaikutuksessa ympäristönsä kanssa, mitä voidaan mitata esimerkiksi kielitaitona tai työllistymisenä. Suomessa asuvien maahanmuuttajien sosiokulttuurista sopeutumista on arvioitu useilla indikaattoreilla. Sosiaali- ja terveysministeriön pakolaisten elämää koskevassa selvityksessä sopeutumisen toteutumista on arvioitu esimerlkiksi työllisyydellä, tuloilla, asumistasolla, tiedotusvälineiden seurannalla, äänestämisellä, kansalaisuuden hakemisella, etnisellä järjestäytymisellä ja paluumuuttohalukkuudella. Lisäksi selvityksessä pyydettiin tietoja ystävien määrästä, äidinkielen ja suomen/ruotsin kielen taidoista, etnisen yhteisön ja oman kulttuurin sekä uskonnon merkityksestä. (Ekholm 1994.)

Perinteisen näkemyksen mukaan kulttuurissa A varttunut henkilö siis 
saavuttuaan kulttuurin B keskelle käy läpi sopeutumisprosessin, jonka jälkeen ja jonka seurauksena hän hyvin yksinkertaistaen joko sopeutuu tai ei sopeudu. Ympäristö, eli kulttuuri B, reagoi maahanmuuttajan sopeutumisprosessiin joko hyväksymällä tai hylkäämällä tulokkaan. Kuvion 1 perinteinen näkemys sopeutumisesta kuvaa sopeutumisen staattisena tilana, jota kohti henkilön tulisi kaikin tavoin pyrkiä.

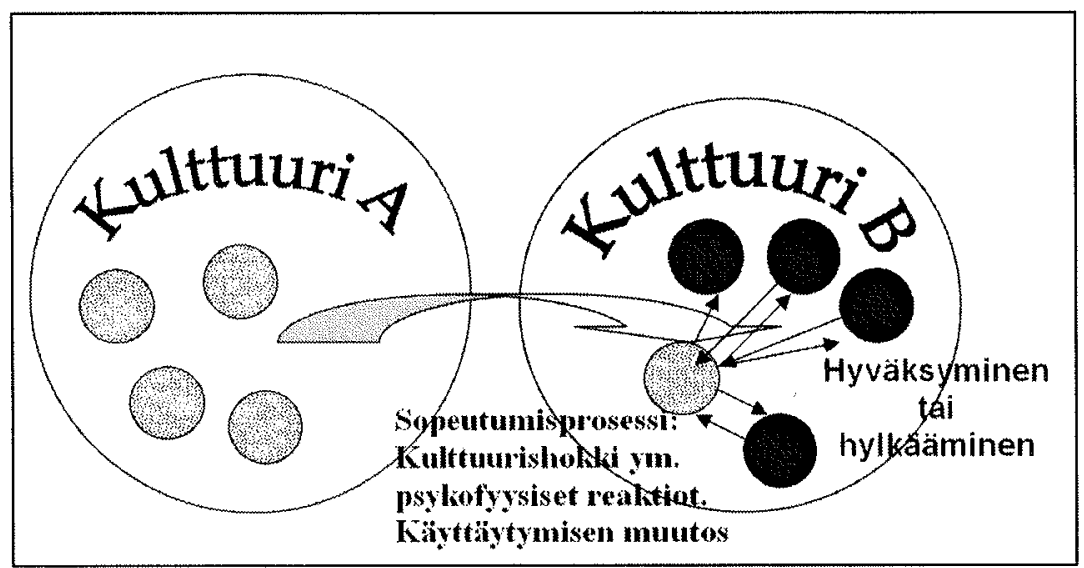

KUVIO 1 Perinteinen ajatus sopeutumisesta. Kuvio on muokattu Luoma-ahon (2006) julkaisemattoman opetusmateriaalin pohjalta.

Sopeutumista tarkastelevia tutkimuksia on paljon, ja tutkimusten lähestymistavat ovat moninaisia. Tutkimuksia voidaan myös pyrkiä jaottelemaan ja jäsentämään sitä kautta, millaisesta näkökulmasta sopeutumista tarkastellaan. Kuviossa 2 on jaoteltu neljä näkökulmaa sopeutumiseen. Kuvatut näkökulmat eivät välttämättä ole toisiaan poissulkevia tai rajaavia. Näkökulmissa voi olla päällekkäisyyksiä esimerkiksi sopeutumisprosessin tavoitteisiin tai sopeutumisprosessiin vaikuttaviin tekijöihin liittyen. Kuvion 2 avulla on kuitenkin mahdollista osoittaa joitakin tekijöitä, joiden avulla näkökulmat voidaan pääpiirteissään erotella toisistaan ja jolloin olemassa olevaa tutkimusta voidaan niiden 


\begin{tabular}{|c|c|c|c|c|}
\hline \multirow{2}{*}{ 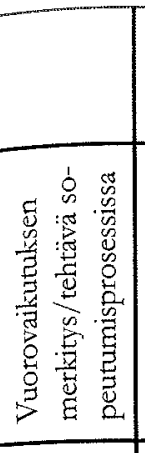 } & \multicolumn{2}{|c|}{$\begin{array}{l}\text { SOPEUTUMINEN NÄHDÄ̈ÄN } \\
\text { STAATTISENA TILANA TAI } \\
\text { OLOMUOTONA }\end{array}$} & \multicolumn{2}{|c|}{$\begin{array}{l}\text { SOPEUTUMINEN ON } \\
\text { DYNAAMINEN PROSESSI } \\
\end{array}$} \\
\hline & 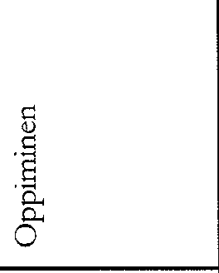 & 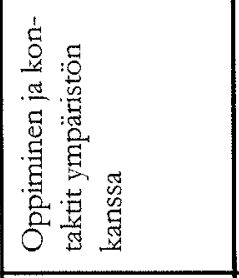 & 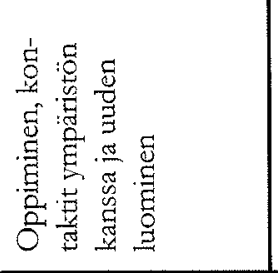 & 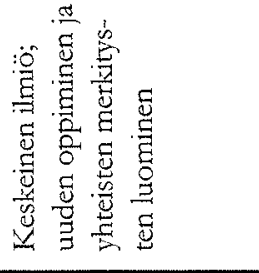 \\
\hline 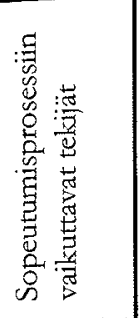 & 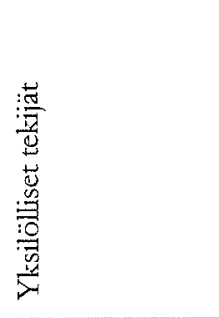 & 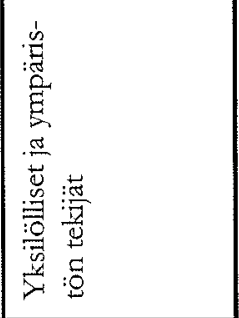 & 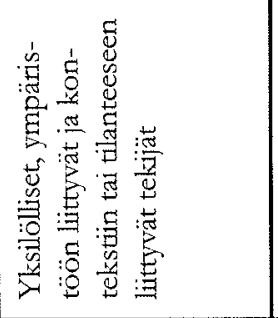 & 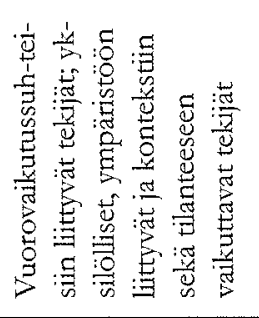 \\
\hline 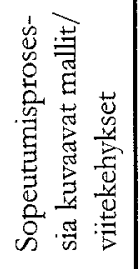 & 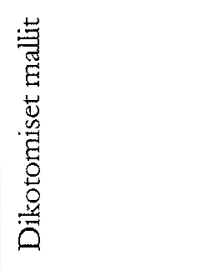 & 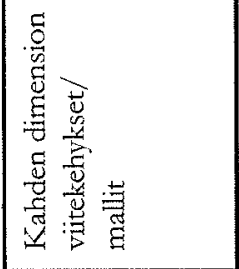 & 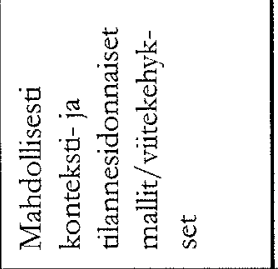 & 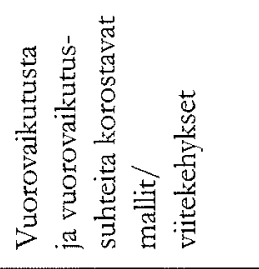 \\
\hline 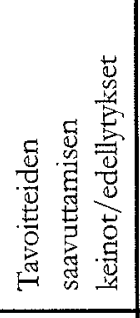 & 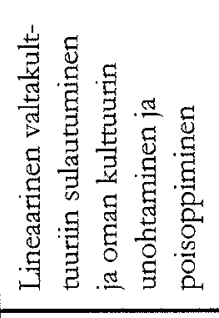 & 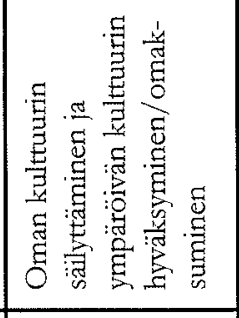 & 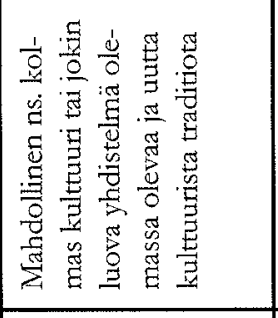 & 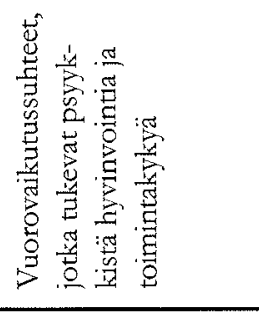 \\
\hline 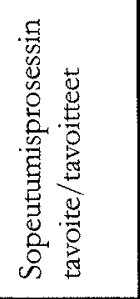 & 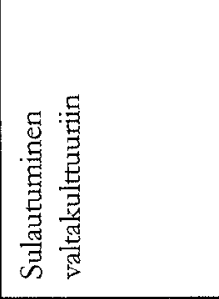 & 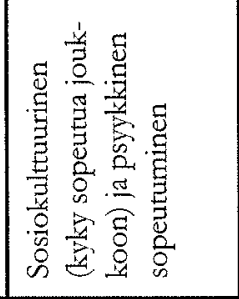 & 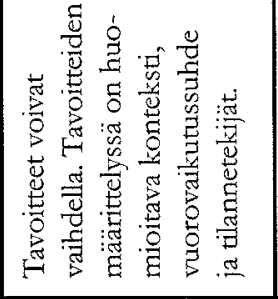 & 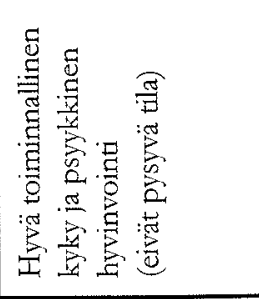 \\
\hline 放 & 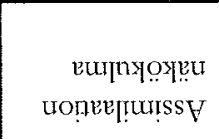 & 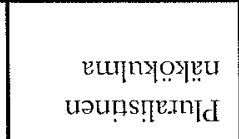 & 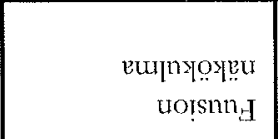 & 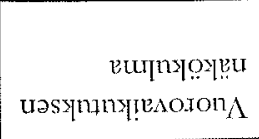 \\
\hline
\end{tabular}


avulla pyrkiä hahmottamaan ja jäsentämään. Näkökulmat on jaoteltu sen mukaan 1) mitkä ja millaiset ovat sopeutumisprosessin tavoitteet ja päämäärät, 2) mitä ovat ne keinot, joilla tavoitteet saavutetaan, 3) millaisia teoreettisia malleja kustakin näkökulmasta on sovellettu, 4) minkä tekijöiden nähdään kussakin näkökulmassa vaikuttavan sopeutumisprosessiin ja 5) millainen tehtävä ja merkitys vuorovaikutuksella nähdään sopeutumisprosessissa olevan.

Sopeutuminen ja sopeutumisprosessi ovat termejä, joita käytetään kirjavasti ja joskus jopa toistensa synonyymeinä. Kahdessa kuviossa 2 esitetyssä näkökulmassa, assimilaation ja pluralismin näkökulmissa, sopeutuminen on märiritelty saavutettavaksi tilaksi tai tunteeksi, joka saavutetaan tai johon pyritään tietynlaisen prosessin kautta tai sen avulla, jolloin näkökulmat noudattelevat pitkälle perinteistä näkemystä sopeutumisesta (ks. kuvio 1). Assimilaation ja pluralismin näkökulmista sopeutuminen voidaan nähdä staattisena, mitattavana ja arvioitavana tilana. Assimilaation näkökulmasta sopeutuminen on sulautumista valtakulttuuriin unohtaen samalla omat kulttuuriset arvot, normit ja toimintatavat. Sopeutumisen tavoitteet on assimilaation näkökulmasta määritelty lähinnä vastaanottavan valtakulttuurin tarpeista ja oletuksista käsin. Henkilön käyttäytyessä kuten valtakulttuurin edustajat, hänen ajatellaan sopeutuneen, jolloin sopeutumisen määrittelyssä korostuu henkilön ulkoinen käyttäytyminen. Assimilaation näkökulma sopeutumiseen lähtee siitä, että sopeutumisprosessi ja muutos ovat lähinnä uuteen kulttuuriin saapuvan henkilön tai ryhmän vastuulla. Samalla kun uuteen kulttuuriseen jmpäristöön tutustuvan yksilön tai ryhmän tulisi omaksua ympäröivän yhteiskunnan arvot, normit ja tavat, assimilaation näkemys yksisuuntaisesta ja lineaarisesta sopeutumisesta pitää sisällään ajatuksen alkuperäisen tai etnisen kulttuurin häviämisestä uuden, usein valtakulttuurin oppimisen myötä (Laroche ym. 1996).

Assimilaation mukaista sopeutumisprosessia voitaisiin kuvata dikotomisena jatkumona, jonka toinen pää edustaa henkilön omaa kulttuuria 
ja vastakkainen pää taas ympäröivän yhteiskunnan tai ryhmän kulttuuria. Lineaarisissa ja yksisuuntaisissa sopeutumista kuvaavissa malleissa ongelma on Roglerin, Cortesin ja Malgadyn (1991) mukaan se, että ne asettavat erilaiset kulttuurit ikään kuin toistensa vastakohdiksi. Näin ei heidän mielestään välttämättä tarvitse olla. Assimilaation tavoite sulautumisesta ympäröivään valtakulttuuriin näyttäisi sitä paitsi nykytiedon ja tutkimuksen valossa olevan lähes mahdoton eikä ainakaan kovin suotava maahanmuuttajien psyykkisen hyvinvoinnin kannalta (Berry 1997; $\operatorname{Kim} 2001)$.

Pluralismi ja pluralismin näkökulma perustuvat ajatukseen, että ryhmät ja yksilöt sällyttävät erilaisten kulttuurien kohdatessa eriasteisia sosiokulttuurisia eroavaisuuksiaan ja erityispiirteitään (Laroche ym. 1996), jolloin ajatellaan, että prosessi voi tapahtua useampiin suuntiin eikä muutos ole aina omasta kulttuurisesta traditiosta poispäin. Pluralismin periaate on, että kaikki kulttuurit ovat yhtä arvokkaita ja että sopeutuminen ympäröivään yhteiskuntaan tapahtuu valikoiden ja kirjavasti erilaisilla sosiokulttuurisilla alueilla (Billig ym. 1988; Redfield, Linton \& Herskovits 1936). Pluralismin näkökulmasta yksilön henkilökohtaisten kokemusten ja tunteiden lisäksi myös ympäristöllä on vaikutulssensa yksilön sopeutumiseen. Yksilön sopeutumista voidaan pluralismin näkökulmasta arvioida muullakin, kuin ulkoisella käyttäytymisellä ja ympäristöön sulautumisella. Käyttäytymisen arvioinnin lisäksi sopeutumisen tavoitteet määritellään henkilön psyykkisen hyvinvoinnin kannalta. Myös käyttäytyminen ja kyky toimia valtakulttuurin parissa perustellaan yksilön hyvinvoinnin kannalta, ei niinkään yhteisön tarpeista käsin (Ward 1997).

Pluralismin näkökulmasta sopeutumista voidaan mitata esimerkiksi omien etnistä vähemmistöä edustavien ja valtakulttuuria edustavien vuorovaikutussuhteiden määrällä. Berry (1997) on nimennyt useita erilaisia sopeutumisstrategioita sen mukaan, kuinka paljon henkilö ylläpitää ja vahvistaa omaa kulttuurista perinnettään edustavia vuorovaikutussuhteita ja kuinka paljon hän on tekemisissä ympäröivän 
valtakulttuurin jäsenten kanssa. Berryn nimeämistä sopeutumisstrategioista integraation sopeutumisstrategiaa on pidetty niin psykologisin kuin sosiokulttuurista sopeutumistakin mittaavin mittarein mitattuna kaikkein toimivimpana (Berry 1980; 1997; Berry \& Kim 1987; Berry ym. 1987; Berry ym. 1989; Berry \& Sam 1997). Integraatio tarkoittaa käytännössä sitä, että henkilö säilyttää omaa kulttuurista perintöään samalla hyväksyen ja omaksuen ympäröivän valtakulttuurin arvoja ja toimintatapoja. Sopeutumisstrategioita tarkastelevat tutkimukset liittyvät usein siihen, millainen strategia johtaa parhaaseen lopputulokseen tai miten se vastaa ympäristön odotuksia (ks. Bourhis ym. 1997; JasinskajaLahti \& Liebkind 1997; Jasinskaja-Lahti ym. 2003). Myös pluralismin näkökulmasta sopeutuminen sïs nähdään tilana ja tavoitteena, jota kohti sopeutumisstrategioiden avulla pyritään.

Vaikka pluralismin näkökulmasta sopeutuminen ympäröivään yhteiskuntaan ajatellaan tapahtuvan valikoiden ja kirjavasti erilaisilla sosiokulttuurisilla alueilla, käytännössä tutkimukset eivät juuri huomioi tätä vaihtoehtoa. Tutkimuksista myös hyvin harvoin ilmenee, miten tämä erilaisilla sosiokulttuurisilla alueilla tapahtuva valikoiva ja kirjava sopeutuminen käytännössä tapahtuu tai ilmenee.

Assimilaation ja pluralismin sopeutumista tarkastelevien näkökulmien rinnalle on esitetty kolmatta, fuusion näkökulmaa. Fuusion näkökulmassa uuden kulttuurisen ympäristön vaikutus henkilön identiteettiin korostuu verrattuna assimilaation ja pluralismin näkökulmiin. Lineaarisessa assimilaation näkökulmassa taustalla on ajatus oman etnisen tai kulttuurisen identiteetin sulauttamisesta valtaväestöön. Pluralistisessa näkökulmassa puolestaan oman etnisen identiteetin säilyttämiselle annetaan jo vaihtoehto. Fuusion näkökulmasta sopeutuva yksilö voi sekoittaa useita kulttuurisia piirteitä uudeksi yhdistetyksi kulttuurikseen (Arends-Tóth \& van de Vijver 2004). Tämä yhdistetty kulttuuri voi pitää sisällään osa-alueita sekä henkilön etnisestä tai kansallisesta kulttuurista että ympäröivän yhteiskunnan valtakulttuurista. 
Toisaalta taas uuteen, yhdistyneeseen kulttuuriin voi sisältyä piirteitä, jotka eivät ole tyypillisiä kummallekaan kulttuurille. Eräs näkemys on, että kun kaksi toisilleen erilaisista kulttuurisista taustoista kotoisin olevaa henkilöä kohtaa, he luovat oman niin kutsutun kolmannen kulttuurinsa, joka perustuu näiden kahden henkilön omiin ja jaettuihin merkityksiin (Casmir \& Asunción-Lande 1990; Hermans \& Kempen 1998).

Fuusion näkökulmasta ihminen nähdään aktiivisena sopeutumisprosessissa toimijana, joka on vuorovaikutuksessa ympäristönsä kanssa ja joka pystyy luovasti soveltamaan erilaisia kulttuurisia normeja ja toimintatapoja. Jotkut ovat jopa sitä mieltä, että ihminen pystyy halutessaan muokkaamaan identiteettiään tilanteiden, voorovaikutussuhteiden ja kontekstin mukaan. Clément ja Noels (1992) raportoivat, että Kanadassa asuvat kiinalaiset maahanmuuttajat voivat tuntea itsensä joko kiinalaisiksi tai kanadalaisiksi rïppuen tilanteesta ja muista läsnä olevista ihmisistä. Fuusion näkökulmasta sopeutumiseen liittyvien muutosten ja tavoitteiden suuntaa voi olla vaikea määrittää. Muutos voi ilmetä kognitiivisena prosessina ja yksilön toimintana, mutta todennäköisesti muutokset näkyvät sekä yksilössä että ympäröivissä yhteisöissä. Tällöin myös sopeutumisen tavoitteita tulisi määritellä sekä yksilön että yhteisön näkökulmasta erilaiset kontekstit ja tilanteet huomioiden.

Neljäs kuviossa 2 esitetty näkökulma on nimetty vuorovaikutuksen näkökulmaksi. Pääpiirteiltään näkökulma noudattelee hyvin pitkälti fuusion näkökulman ajatuksia ja näkemyksiä. Vuorovaikutuksen näkökulmasta sopeutumisen nähdään kuitenkin vielä voimakkaammin olevan tässä ja nyt tapahtuva ja ilmenevä prosessi, ei ainoastaan tavoite, jonka saavuttamista pyritään arvioimaan tai mittaamaan. Sopeutuminen nähdään prosessina, jonka tavoitteet muuttuvat jatkuvasti tilanteiden, kontekstien ja vuorovaikutussuhteiden mukaan. Sïnä missä perinteinen näkemys sopeutumisesta käsittää sopeutumisen kahden kulttuurin vuoropuheluna tai taisteluna, fuusion ja vuorovaikutuksen näkökulmista sopeutumisen nähdään tapahtuvan tilanteissa, joissa lukuisat erilaiset 
kulttuuriset tavat ja traditiot kohtaavat lukuisissa vuorovaikutussuhteissa ja tilanteissa (ks. kuvio 3).

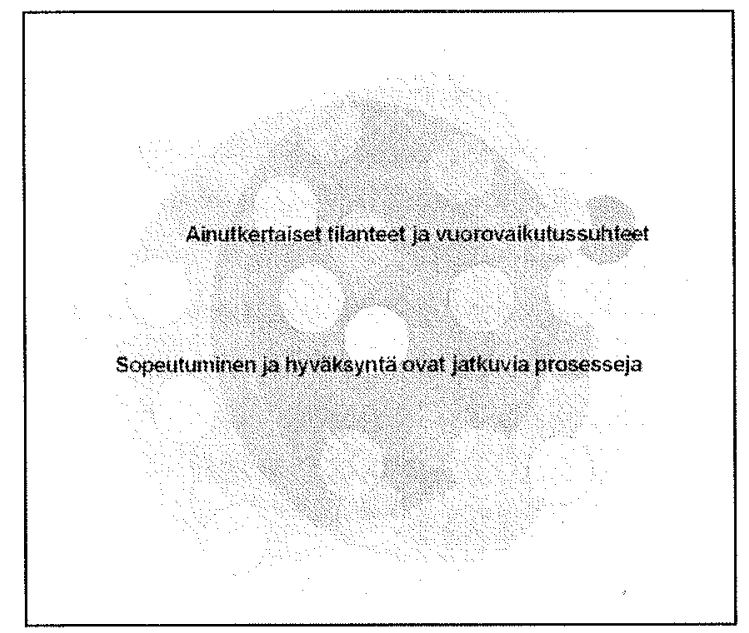

KUVIO 3 Vuorovaikutuksen näkökulma sopeutumiseen.

Kuvio on muokattu Luoma-ahon (2006) julkaisemattoman opetusmateriaalin pohjalta.

Kuviossa 3 kuvattua vuorovaikutuksen näkökulmaa sopeutumiseen voidaan havainnollistaa vielä kuvitteellisella esimerkillä Afganistanista Suomeen saapuneista pakolaisista. Afganistanista saapuvat pakolaiset ovat usein asuneet vuosia, jopa kymmeniä vuosia Pakistanissa pakolaisleirillä ennen Suomeen tuloaan. Pakolaisleirillä on syntynyt vuorovaikutussuhteita, jotka edustavat jo uudenlaista kulttuurista perinnettä. Perheiden lapset saattavat olla syntyneet pakolaisleirillä, jolloin heidän kosketuksensa afganistanilaiseen kulttuuriin on perheen ja pakolaisleirillä asuvien muiden samalta alueelta lähtöisin olevien tuottamaa kulttuurista perinnettä. Saavuttuaan Suomeen pakolaiset solmivat vuorovaikutussuhteita usein muihin maahanmuuttajiin. Usein sama etninen tausta tai yhteinen kieli tuntuvat helpottavan vuorovaikutusta niin, että 
ihmisiin tutustutaan mielellään ja ystävyyssuhteita syntyy esimerkiksi kurdien kesken riippumatta siitä, ovatko he lähtöisin Iranista, Irakista vai Afganistanista. Afganistanilainen pakolainen voi asioida venäläissyntyisen lääkärin vastaanotolla ja opiskella Suomen yhteiskuntaoppia Somaliasta kotoisin olevan opettajan avustuksella. Suomeen tulleiden pakolaisten ja muiden maahanmuuttajien vuorovaikutussuhteet harvoin kai edustavat vain kahta selkeäpiirteistä kulttuurista ryhmää. Maahanmuuttaja voi kokea olevansa sopeutunut tiettyyn kaupunginosaan ja sen elämänrytmiin, mutta aloittaa sitten työt uudessa työpaikassa, jossa vastassa on uudenlainen työkulttuuri, johon on sopeuduttava. Kun sopeutuminen nähdään kuuluvaksi ihmisen perusluonteeseen, oleellista ei ole pyrkiä tarkastelemaan tai arvioimaan, sopeutuvatko ihmiset, vaan kysymys on pikemminkin siitä, miten ihmiset sopeutuvat, Kim $(2001,58)$ toteaa.

Vuorovaikutuksen näkökulma sopeutumiseen kuvaa monikulttuurisissa ympäristöissä toimivia yksilöitä, jotka luovasti ja tilanteen mukaan rakentavat yhteistä todellisuutta olemalla vuorovaikutuksessa keskenään. Kuvio 3 havainnollistaa erilaisten todellisuuksien päällekkäisyyttä ja monimuotoisuutta, jossa yhtä kulttuurista ympäristöä on lopulta edes mahdotonta erottaa itsenäiseksi, muista irralliseksi kokonaisuudeksi.

\section{VUOROVAIKUTUS SOPEUTUMISESSA}

Vuorovaikutus sinänsä ei ole uusi käsite sopeutumista tarkastelevissa tutkimuksissa. Muistakin näkökulmista tehdyissä tutkimuksissa on puhuttu vuorovaikutuksesta ja sen merkityksestä (esim. Berry 1997; Black 1988; Bourhis ym. 1997). Esimerkiksi Jaskinskaja-Lahti ja Liebkind (1997) ovat tarkastelleet Suomeen tulleiden maahanmuuttajien sopeutumista pääkaupunkiseudulle, ja yhtenä osa-alueena tässä sosiaalipsykologian tutkimulksessa ovat maahanmuuttajien akkulturaatiostrategiat, joita tutkijat ovat soveltaneet Berryn (esim. 1997) sopeu- 
tumisstrategioiden pohjalta. Jasinskaja-Lahti ja Liebkind (1997, 14) selittävät akkulturaatiostrategioiden muodostuvan juuri vastauksista kahteen peruskysymykseen: miten tärkeää on säilyttää omaa kulttuurista taustaa ja elämäntapaa uudessa kulttuurissa ja minkälaiset suhteet tulisi muodostaa valtaväestöön tai valtakulttuuriin. Ennustaessaan maahanmuuttajien akkulturaatiostrategioita tutkijat eivät kuitenkaan ole tarkastelleet maahanmuuttajien vuorovaikutussuhteita sinänsä, vaan selittävinä tekijöinä on tarkasteltu maahanmuuttajien identiteettiä mittaavia muuttujia, perhearvoja mittaavia muuttujia ja maahanmuuttajien kielitaitoa ja kielten käyttöä mittaavia muuttujia (Jasinskaja-Lahti \& Liebkind 1997, 50).

Vuorovaikutuksen merkitys tulee esille myös tutkimuksessa, jossa Jasinskaja-Lahti, Liebkind, Horenczyk ja Shmitz (2003) ovat tarkastelleet rinnakkain nuorten maahanmuuttajien ja ympäristön asenteita sopeutumiseen liittyen. Tulokset osoittavat, että Suomessa ympäristön asettamat odotukset maahanmuuttajien assimilaatiosta johtivat maahanmuuttajien kohdalla voimakkaisiin stressioireisiin erityisesti silloin, kun maahanmuuttajan itsensä kannattama sopeutumisstrategia oli lähempänä integraatiota. Ristiriitaiset odotukset johtivat tutkimuksen mukaan syrjintään ja aiheuttivat stressioireita maahanmuuttajille myös Israelissa ja Saksassa. Ylipäänsä ne maahanmuuttajat, joiden odotukset sopeutumisesta olivat eniten ristiriidassa ympäröivän yhteiskunnan odotusten kanssa, kokivat eniten syrjintää ja raportoivat voimakkaista stressioireista. Tutkimuksissa on siis tarkasteltu molempien osapuolten odotuksia ja toiveita sopeutumisen suhteen, jolloin asetelmaa voidaan jo pitää hyvinkin vuorovaikutteisena. Berry (1997) onkin todennut, että sopeutumisstrategiasta voidaan puhua vasta sitten, kun maahanmuuttajan valitsema strategia voidaan toteuttaa kyseisessä ympäristössä niin, että vastaanottava ympäristö sen hyväksyy. Kuten edellä esitetyissä tutkimuksissa, vuorovaikutusta eri osapuolten välillä pidetään usein edellytyksenä sopeutumiselle, mutta hyvin harvoissa tutkimuksissa lopulta tarkastellaan 
itse vuorovaikutussuhteita syvällisesti tai problematisoiden.

Kim (2001) on teoksessaan Becoming intercultural esittänyt mallin sopeutumisesta ja vuorovaikutuksesta. Kim ei kuitenkaan itse puhu vuorovaikutuksen näkökulmasta, eikä Kim esimerkiksi tee selkeää eroa sopeutumisen ja sopeutumisprosessin välille. Kimin $(2001,31)$ mukaan sopeutuminen on dynaaminen prosessi, jossa yksilöt tullessaan uuteen, tuntemattomaan tai muuttuneeseen kulttuutiseen ympäristöön muodostavat ja ylläpitävät suhteellisen pysyviä vastavuoroisia ja toimivia suhteita ympäristöjensä kanssa. Hänen mukaansa vuorovaikutus on nimenomaan se prosessi, joka mahdollistaa viestien vaihtamisen ja merkitysten syntymisen, uuden oppimisen ja itselle vieraaseen sopeutumisen. Kim siis puhuu sopeutumisesta prosessina, jossa ihmiset ovat jatkuvasti vuorovaikutuksessa keskenään ja vaihtavat näin informaatiota puolin ja toisin. Hänen mukaansa ihminen tuottaa vuorovaikutuksessa informaatiota ympäristölleen ja vastaavasti luo sisäisiä merkityksiä ympäristöstä tulevalle tiedolle ja palautteelle. (Kim 2001, 31.)

Toisaalta Kimin (2001) mukaan sopeutuminen uuteen kulttuuriin tarkoittaa vuorovaikutuksen kautta ja siinä osallisena olemisesta aiheutuvia ihmisen sisäisiä muutoksia, joiden tuloksena henkilön toiminnallinen kyky (functional fitness), psyykkinen hyvinvointi (psychological health) ja kulttuurienvälinen identiteetti (intercultural identity) vahvistuvat (Kim 2001, 183-193). Kim myös kuvaa sopeutumista syklisenä spiraalimaisena prosessina, joka kyllä näyttäisi yhä etenevän sopeutumisen jatkumolla kohti asetettuja tavoitteita. Vuorovaikutuksen näkökulma on saanut paljon aineksia Kimin esittämistä ajatuksista ja teoreettisista näkemyksistä. Vuorovaikutuksen näkökulman yksi keskeinen ajatus on Kimin ajatus siitä, että sopeutuminen tapahtuu ja ilmenee vuorovaikutuksessa. Vuorovaikutuksen näkökulma korostaakin vuorovaikutussuhteita. Myös Kim puhuu vuorovaikutussuhteiden kehittymisestä ja niiden ylläpitämiseen liittyvistä ilmiöistä ja teorioista, mutta hyvin pinnallisesti. ( $\operatorname{Kim} 2001,183-193$. 


\section{VUOROVAIKUTUSSUHTEIDEN MERKITYS SOPEUTUMISESSA}

Ajallisesti vuorovaikutuksen näkökulman perusajatukset eivät ole uusia, mutta tutkimukset, joissa vuorovaikutuksen näkökulmaa sovellettaisiin maahanmuuttajien sopeutumisen tarkasteluun, ovat vielä kovin harvinaisia. Maahanmuuttajien vuorovaikutussuhteista sen sijaan on jonkin verran tietoa. Useissa Suomeen tulleiden maahanmuuttajien sopeutumista tarkastelevissa tutkimuksissa vuorovaikutussuhteet nähdään yhtenä muuttujana ja osana sopeutumista (Alitolppa-Niitamo 1994; Ekholm 1994; Hyttinen \& Tikkanen 1997; Pohjanpää, Paananen \& Nieminen 2003; Rommakkaniemi 1997; Salminen 1997; Valtonen 1994; 1998). Vuorovaikutussuhteet voidaankin nähdä yhdeksi merkittäväksi tekijäksi sopeutumisprosessissa tai ne voidaan asettaa sopeutumisprosessin keskiöön (ks. kuva 3). Vaikka vuorovaikutuksen näkökulmassa vuorovaikutussuhteet ja vuorovaikutus itsessään ovat sopeutumisen keskiössä, ei näkökulma kiellä muiden asioiden merkitystä tai vaikutusta sopeutumisprosessiin. Kim (2001) on jakanut sopeutumisprosessiin vaikuttavat tekijät neljään ryhmään, jotka ovat 1) henkilön tausta ja lähtökohdat, 2) ympäristö, johon sopeudutaan, 3) sopeutumisen tavoitteet ja 4) henkilökohtainen ja sosiaalinen vuorovaikutus. Vaikka henkilökohtainen ja sosiaalinen vuorovaikutus nostetaan myös yhdeksi sopeutumiseen vaikuttavaksi tekijäksi, on $\operatorname{Kim}(2001,72)$ todennut, että vuorovaikutus on kaiken keskiössä, jolloin myös henkilön tausta ja lähtökohdat, ympäristö ja saavutettavat tavoitteet voidaan nähdä vuorovaikutuksen näkökulmasta. Sopeutumiseen liittyvät lukuisat henkilökohtaiset ja ympäristötekijät vaikuttavat simultaanisti ja vuorovaikutteisesti toinen toiseensa ja samalla koko sopeutumisprosessiin (Kim 2001, 37).

Vuorovaikutuksen näkökulmasta sopeutumista on tutkittu varsin vähän, mutta vuorovaikutussuhteista ja sopeutumisesta on silti saatavilla tutkittua tietoa (esim. Ahmad 2005; Alitolppa-Niitamo 1994; Ekholm 1994; Forsander 2002; Hyttinen \& Tikkanen 1997; Pehkonen 
2006; Pohjanpää, Paananen \& Nieminen. 2003; Rommakkaniemi 1997; Salminen 1997; Valtonen 1994; 1998). Yleensä vuorovaikutussuhteiden tarkastelu on sopeutumista tarkastelevissa tutkimuksissa kuvailevaa, jolloin tuloksina kerrotaan, millaisia vuorovaikutussuhteita maahanmuuttajilla on tai ei ole. Esimerkiksi Pohjanpää (2003) on tarkastellut venäläisten, virolaisten, somalialaisten ja vietnamilaisten maahanmuuttajien sosiaalisia suhteita osana laajaa maahanmuuttajien elinoloja kartoittavaa tutkimusta. Vuorovaikutussuhteita koskevat kysymykset liittyivät tämän tutkimuksen puitteissa yksinäisyyteen, ystäryyssuhteisiin, naapurisuhteisiin ja muualla eläviin sukulaisiin. Lisäksi vastaajien sosiaalisiin suhteisiin liittyvissä kysymyksissä kysyttiin muutamalla kysymylksellä maahanmuuttajien sosiaalisesta ja yhteiskunnallisesta aktiivisuudesta. Tutkimuksessa kävi ilmi, että maahanmuuttajat tuntuivat solmivan ystävyyssuhteita erityisesti maanmiestensä kanssa, kun samaan aikaan muiden ulkomaalaisten tunteminen oli tutkimukseen osallistuneiden maahanmuuttajien keskuudessa harvinaisempaa. Tutkimukseen osallistuneilla maahanmuuttajilla näyttäisi myös olevan suomalaisia ystäviä, ja naapurussuhteita pidettiin erityisesti vietnamilaisten keskuudessa hyvinä. (Pohjanpää 2003, 136.)

Vuorovaikutuksen näkökulmasta sopeutuminen on siis prosessi, jossa henkilö pyrkii luomaan ja ylläpitämään mahdollisimman monipuolisia vuorovaikutussuhteita, jotka tukisivat henkilön psyykkistä hyvinvointia ja kykyä toimia uudessa tai muuttuneessa ympäristössä. Nämä tavoitteet tulevat hyvin lähelle aiemmin esitettyjä Wardin (1997) sekä Wardin ja kumppaneiden (esim. Searle \& Ward 1990; Ward, Bochner \& Furnham 2001; Ward \& Kennedy 1992; Ward \& Searle 1991) ajatuksia psyykkisestä ja sosiokulttuurisesta sopeutumisesta. Ward sekä Ward kollegoineen viittaavat sosiokulttuurisella sopeutumisella henkilön kykyyn sopeutua häntä ympäröivään ihmisjoukkoon. $\operatorname{Kim}(2001,185)$ puolestaan puhuu toiminnallisesta kyvystä ja tarkoittaa tällä sitä, että maahanmuuttajat oppivat vuorovaikutuksessa, kuinka uudessa ympäristössä ja sen arki- 
päiväisissä askareissa toimitaan. Henkilö esimerkiksi tietää, mistä saa erilaisia palveluja tai miten pääsee liikkumaan paikasta toiseen.

Ajatus sosiokulttuurisesta sopeutumisesta tai Kimin (2001, 185-187) ajatus hyvästä toiminnallisesta kyvystä ja vuorovaikutuksesta oppimisen ja sopeutumisen keinona on yksilökeskeinen, eikä lopulta kovin vuorovaikutuksellinen. Vielä pidemmälle vietynä toiminnallisella kyvyllä voitaisiin vuorovaikutuksen näkökulmasta tarkoittaa myös kykyä olla vuorovaikutuksessa niin, että vuorovaikutuksen kaikilla osapuolilla olisi mahdollisuus oppia. Tällöin hyvä toiminnallinen kyky mahdollistaisi myös uusien merkitysten ja omanlaisen kulttuurisen toimintamallin luomisen.

Henkilön psyykkisen hyvinvoinnin, stressin, henkilökohtaisten vuorovaikutussuhteiden ja uuteen kulttuuriin sopeutumisen väliltä on löydetty yhteyksiä useissa tutkimuksissa (esim. Kim, Lujan \& Dixon 1998; Nishida 1985; Searle \& Ward 1990; van Oudenhoven \& Eisses 1998; Ward ym. 1998). Kim (2001, 187-190) viittaa psyykkisellä hyvinvoinnilla olotilaan, jossa henkilön kognitiviset, affektiiviset ja operationaaliset pyrkimykset ovat tasapainossa keskenään. Hänen mukaansa psyykkistä hyvinvointia on ulkopuolisen hankala havaita, mutta toisaalta oireet psyykkisistä ongelmista tai pahoinvoinnista ovat selkeästi diagnosoitavissa. Psyykkisen pahoinvoinnin oireita voivat olla esimerkiksi negatiivinen kuva itsestä, huono itsetunto, sosiaalinen eristäytyminen tai yleinen tyytymättömyys elämään (ks. myös Dylan \& Dylan 1981; Searle \& Ward 1990). Koska vuorovaikutuksen näkökulmasta psyykkisen hyvinvoinnin tai hyvän toimintakyvyn tavoitteet eivät ole pysyvä tai staattinen tila, oleellista olisi pyrkiä ymmärtämään, mikä merkitys vuorovaikutussuhteilla on maahanmuuttajien psyykkisessä hyvinvoinnissa ja toimintakyvyssä.

Vuorovaikutussuhteita voidaan jo itsessään pitää hyvin merkityksellisinäihmisten psyykkisen hyvinvoinnin kannalta. Vuorovaikutussuhteissa maahanmuuttajat voivat jakaa itselleen tärkeitä ja läheisiä asioita ja puhua 
esimerkiksi tunteistaan. Moskeijan yhteyteen kokoontuneiden ihmisten ja vuorovaikutussuhteiden merkitys ei Suomen suurimmissa kaupungeissa asuville muslimipakolaisille ole ainoastaan uskonnollinen, vaan moskeijaa pidetään tärkeänä paikkana myös siksi, että siellä tavattavien ystävien ja tuttavien kanssa pakolaiset voivat keskustella uuteen kulttuuriin sopeutumisen haasteista ja haasteet voidaan ikään kuin kohdata yhdessä (Valtonen 1998). Vuorovaikutussuhteet mahdollistavat kokemuksen kuulumisesta johonkin, ja vuorovaikutussuhteiden voidaankin nähdä liittävän yksilön yhteisöön (Hurh \& Kim 1990).

Vuorovaikutussuhteissa myös omaa identiteettï̈ rakennetaan ja vahvistetaan uudessa tai muuttuneessa ympäristössä (Knudsen 1988). Vuorovaikutuksessa ja sen kautta yksilö peilaa itseään ympärillään oleviin ihmisiin ja vahvistaa tai muuttaa käsityksiään itsestään yhteisön jäsenenä tai yhteisöön kuulumattomana henkilönä ( $\operatorname{Kim} 2001,72$; ks. myös Rogers 1998, 77; Sigman 1998, 52). Monet tutkijat ovatkin nostaneet myös maahanmuuttajan identiteetin tärkeään rooliin sopeutumisen tarkastelussa (esim. Phinney 1993).

Suomalaisessa politiikassa ja kirjallisuudessa käytetään myös termiä kotoutuminen pakolaisten sopeutumisesta puhuttaessa (esim. Lepola 2002). Mielestäni maahanmuuttajien sopeutumisessa onkin usein kysymys siitä, että maahanmuuttajat voivat tuntea olonsa kotoisaksi uudessa ympäristössään. Vuorovaikutussuhteilla on oma merkittävä roolinsa siinä, että joku paikka tuntuu kodilta. Suomessa asuvien mahanmuuttajien kertomukset kodista ja sen merkityksestä paljastavat, kuinka Suomeen muualta muuttaneet henkilöt kaipaavat takaisin entiseen asuinmaahansa siellä olevien vuorovaikutussuhteiden takia.

Huttunen (2002) on väitöskirjatutkimuksessaan tarkastellut kodin merkityksiä Suomessa asuvien maahanmuuttajien omaelämäkerroissa. Aineisto koostuu yli 70 kirjoituskilpailuun osallistuneen maahanmuuttajan tekstistä. Kertomuksissa koti ja merkitykselliset vuorovaikutussuhteet liittyvät kiinteästi toisiinsa. Entisestä Neuvostoliitosta Suomeen 
muuttanut henkilö kaipaa ystäviään ja työtovereitaan, koska niukoista resursseista ja ahtaista asuinolosuhteista huolimatta juuri vuorovaikutussuhteet mahdollistivat tunteen kuulumisesta ja kodista. Huttunen $(2002,63)$ toteaa, että ihmissuhteet ja sosiaaliset verkostot kodin tuottajina korostuvat myös vietnamilaisen naisen tarinassa ja että "maantieteelliset paikat tulevat kodeiksi lopulta ihmissuhteiden ja verkostojen kautta". Naisen tarinasta käy ilmi, kuinka Suomessa solmittu avioliitto ja täällä syntynyt lapsi kiinnittävät kertojan tiiviisti uuteen ympäristöönsä. Näiden vuorovaikutussuhteiden myötä Suomesta on tullut kirjoittajan uusi kotimaa. Huttunen $(2002,65)$ toteaa, että uuteen maahan muuttamiseen, jäämiseen tai lähtemiseen liittyvät ratkaisut tehdään usein ennen kaikkea perheen ehdoilla. Perheestä ja vuorovaikutussuhteista tulee maahanmuuttajille mukana kulkeva, matkustava koti. Myös ystävyyssuhteiden merkitys sopeutumiskokemuksissa nousee Huttusen aineistossa esille, ja se näkyy esimerkiksi tarinassa, jossa kirjoittaja kertoo kaipaavansa aikaa vankileirin sietämättömissä oloissa siellä olleiden ystäviensä vuoksi.

Psyykkiseen hyvinvointiin liittyvien seikkojen lisäksi sopeutumista voidaan tarkastella toiminnallisena kykynä tai sosiokulttuurisena sopeutumisena, jolloin myös vuorovaikutussuhteet ovat merkittävässä roolissa. Sosiokulttuurinen sopeutuminen voidaan määritellä uuteen kulttuuriin tulijan kyvyksi sopeutua joukkoon tai kykyyn olla vuorovaikutuksessa ympäröivän kulttuurin edustajien kanssa (Searle \& Ward 1990, 450). Kyky sopeutua joukksoon vaatii tietoa uudesta ympäristöstä, sen tavoista ja normeista, jolloin interpersonaaliset vuorovaikutussuhteet ovat keskeisessä roolissa maahanmuuttajan hankkiessa tietoa paikallisten ihmisten tavoista ja ajatuksista. Vuorovaikutustilanteet tarjoavat maahanmuuttajille mahdollisuuden sekä oman että toisten viestintätapojen tarkkailuun ja testaamiseen. Jokainen vuorovaikutustilanne tarjoaa mahdollisuuden harjoittaa ja kehittää omia vuorovaikutustaitoja uudessa ympäristössä. Vuorovaikutussuhteet siis tarjoavat tietoa ympä- 
röivästä kulttuurista ja ohjeita siitä, mikä on sosiaalisesti hyväksyttyä ja milkä puolestaan ei (Ho \& Sung 1990; Milroy 1987). Samalla kun maahanmuuttajat oppivat vuorovaikutussuhteiden kautta, kuinka toimia uudessa ympäristössä, he myös saavat palautetta siitä, kuinka he ovat oppineet ja kuinka he pärjäävät ( $\operatorname{Kim} 2001,123)$. Vuorovaikutussuhteet myös mahdollistavat uusien yhteisten toimintatapojen ja merkitysten luomisen, jolloin esimerkiksi ns. kolmannen kulttuurin mahdollisuus voisi todentua maahanmuuttajien arjessa.

Kielitaitoa pidetään yhtenä edellytyksenä sille, että henkilö kykenee toimimaan uudessa vieraskielisessä ympäristössään. Kielitaidon ja vuorovaikutussuhteiden välistä yhteyttä voidaan tarkastella niin, että usein ne maahanmuuttajat, jotka ovat vuorovaikutuksessa ympäröivän yhteiskunnan valtaväestön edustajien kanssa, kokevat, että heidän kielitaitonsa on hyvä. Laajassa, vuosituhannen vaihteessa tehdyssä Suomessa asuvien maahanmuuttajien elinoloja tarkastelevassa tutkimuksessa kävi ilmi, että ne maahanmuuttajat, joilla oli suomalaisia ystäviä, pitivät omaa suomen kielen taitoaan hiukan parempana kuin mut tutkimuksessa mukana olleet maahanmuuttajat (Pohjanpää 2003). Selityksenä voi olla se, että suomalaiset ystävät auttavat kielenoppimista tarjoamalla mahdollisuuksia kielen käyttämiseen ja esimerkiksi uusien sanojen oppimiseen. Yhteinen kieli on siis myös vuorovaikutussuhteiden näkökulmasta erittäin keskeinen tekijä sopeutumisessa, sillä se näyttäisi edistävät uusien vuorovaikutussuhteiden solmimista. Toisaalta vuorovaikutussuhteet voivat omalta osaltaan vahvistaa henkilön kielitaitoa.

Sopeutumisen kaksi osa-aluetta, psyykkinen hyvinvointi ja kyky toimia uudessa tai muuttuneessa ympäristössä, voidaan nähdä teoreettisesti ja empiirisesti erillisinä kokonaisuuksina, vaikka ne liittyvätkin kiinteästi toisïnsa (ks. Ward 1997, 60). Toimintakykyyn liittyvillä taidoilla, kuten kielitaidolla, on varmasti vaikutuksensa siihen, että henkilö voi tutustua ihmisiin, joilta voi saada sosiaalista tukea. Sosiaalisen tuen saaminen puolestaan vaikuttaa henkilön psyykkiseen hyvinvointiin ja 
tyytyväisyyteen. Psyykkinen hyvinvointi, kuten tyytyväisyys nykyiseen elämäntilanteeseen, vaikuttaa puolestaan varmasti siihen, miten motivoitunut henkilö on esimerkiksi uuden kielen oppimiseen. Kielitaidon puolestaan voidaan nähdä auttavan henkilöä tulemaan toimeen uudessa ympäristössään. Esimerkiksi Suomessa työnhakutilanteissa maahanmuuttajilta odotetaan erinomaista kielitaitoa ja hyvä suomen kielen hallinta näyttäisi olevan edellytys työpaikan saamiseksi. Toisaalta tutkimukset myös osoittavat, että hyväkään kielitaito ei aina riitä. Sopivan koulutuksen ja työkokemuksen lisäksi maahanmuuttajien henkilökohtaiset vuorovaikutussuhteet näyttävät olevan hyvin merkittävässä roolissa maahanmuuttajien työllistymisessä. Tietoa työpaikoista ja koulutusmahdollisuuksista saadaan usein epävirallisia kanavia pitkin, ystäviltä ja tuttavilta. (Ahmad 2005; Forsander 2002.)

Stressaavassa elämäntilanteessa, kuten muutettaessa maasta toiseen, vuorovaikutussuhteet mahdollistavat esimerkiksi sosiaalisen ja emotionaalisen tuen antamisen ja vastaanottamisen (Mortland \& Ladgerwood 1988; Valtonen 1998). Sosiaalinen ja emotionaalinen tuki puolestaan auttavat henkilöä sopeutumiseen liittyvien stressiä aiheuttavien tekijöiden hallinnassa. Maahanmuuttajien vuorovaikutussuhteet tarjoavat monenlaista tukea ja apua. Valtosen $(1994 ; 1998)$ mukaan Suomessa asuvien pakolaisten sopeutumiseen liittyvistä tutkimuksista ilmee, että varsinkin prosessin alkuvaiheessa vuorovaikutussuhteet ja niiden muodostamat verkostot toimivat epämuodollisina tukiryhminä uuteen kulttuuriseen ympäristöön saapuville. Apua tarvitaan, kun oma kielitaito ei riitä ymmärtämään uutisia, virallisia papereita tai terveydenhuollon ajanvarausjärjestelmää. Maahanmuuttajien saama käytännön apu vaihtelee hakemuslomakkeiden ja veroilmoitusten täyttämisestä tulkkaukseen, auton korjaamiseen, muuttoapuun tai lastenhoitoapuun. Vuorovaikutussuhteista saadaan apua arkipäivän rutiinien hoitamiseen, kuten virastoissa asioimiseen ja asunnon tai työpaikan löytymiseen (Ahmad 2005; Forsander 2002; Hagan 1998; Valtonen 1994; 1998). 
Myös kriiisitilanteissa, kuten perheväkivaltatapauksissa, suojaa saadaan ystävien ja tuttavien luota (Hautaniemi 2004; Valtonen 1994; 1998).

\section{LOPUKSI}

Rogers ja Kincaid $(1981,45)$ ovat todenneet, että henkilökohtaiset vuorovaikutussuhteet antavat yksilölle hänen merkityksensä. He puhuvat vuorovaikutusverkostoista ja tarkoittavat tällä vuorovaikutussuhteiden muodostamia verkostoja, joissa henkilö on osallisena, jolloin asia voitaneen ilmaista myös niin, että henkilön kaikki vuorovaikutussuhteet yhdessä antavat yksilölle hänen merkityksensä. Vuorovaikutussuhteet nähdäänkin sopeutumisessa ja sopeutumisprosessissa näkökulmasta huolimatta tärkeinä ja vuorovaikutussuhteiden tarkastelua sopeutumisprosessin yhteydessä voidaan pitää erittäin perusteltuna. Vuorovaikutussuhteiden problematisointi on kuitenkin jäänyt sopeutumista tarkastelevissa tutkimuksissa hyvin vähäiseksi.

Vuorovaikutuksen näkökulma ei ole ajallisesti kovinkaan uusi, mutta uuteen elämäntilanteeseen, kuten uuteen kulttuuriseen ympäristöön sopeutumisen tarkasteluun se tarjoaa erilaisen, ehkä innovatiivisenakin pidettävän näkökulman. Kehityspsykologinen näkemys sopeutumisesta auttaa hahmottamaan ja erottelemaan muutokseen ja sitä selviytymiseen liittyviä tekijöitä ja muuttujia. Jos sopeutuminen nähdään ontologiselta luonteeltaan vuorovaikutukselliseksi prosessiksi, vuorovaikutussuhteiden tarkastelu ja vuorovaikutuksen näkökulma tarjoavat hyvän lisän tieteelliseen keskusteluun.

Sopeutumisen lisälssi myös vuorovaikutussuhteita voidaan tarkastella dynaamisesti kehittyvinä ja ylläpidettävinä kokonaisuuksina. Vuorovaikutussuhteiden kehittymistä ja erityisesti läheisyyden kehittymistä suhteessa on kuvattu lineaarisella jatkumolla (esim. Altman \& Taylor 1973; Knapp \& Vangelisti 1992; Wilmot 1987), mutta niiden voidaan nähdä myös kehittyvän jatkuvana prosessina. Baxterin ja 
Montgomeryn $(1996 ; 1997)$ vuorovaikutussuhteiden jännitteiden teoria kuvaa suhdetta jatkuvana ja jatkuvasti muuttuvana prosessina. Teorian mukaan vuorovaikutussuhteet kyllä kehittyvät ja muuttuvat jatkuvasti, mutta muutoksen suuntana ei aina ole läheisempänä koettu olotila suhteessa. Teoria ei kiellä, ettei suhteessa koettu läheisyys voisi syvetä ajan kuluessa ja suhteen kehittyessä. Keskeinen ajatus kuitenkin on, että suhteessa voi tapahtua muutoksia myös muihin suuntiin, ilman että se tarkoittaa suhteen hiipumista, loppumista tai menettämistä. Kun vuorovaikutussuhteet nähdään jatkuvasti muuttuvina kokonaisuuksina, myös sopeutumisen näkeminen dynaamisena prosessina olisi luontevaa.

Vuorovaikutuksen näkökulma tarjoaa fokusoidun näkökulman pohdittaessa sopeutumiseen ja vuorovaikutussuhteisiin liittyviä kysymyksiä. Jotta todella ymmärrettäisiin esimerkiksi pakolaisten interpersonaalisia vuorovaikutussuhteita ja sopeutumisen dynamiikkaa, lisäselvitystä ja empiiristä tutkimusta kaivattaisiin kuitenkin lisää. Kiinnostavia olisivat esimerkiksi kysymykset siitä, miten yhtäältä omaa kulttuurista taustaa ja toisaalta uusia tapoja ja arvoja sovelletaan käytännön vuorovaikutussuhteissa. Erityisesti lisäselvitystä kaipaisivat Suomessa asuvien maahanmuuttajien itsensä sopeutumiselle asettamat tavoitteet ja näkemykset sopeutumisesta. Fuusion ja vuorovaikutuksen näkökulmat tarjoaisivat myös mahdollisuuden nähdä, millaisessa roolissa pakolaiset kokevat itsensä uusien kulttuuristen tapojen muokkaajina.

Tähänastisissa tutkimuksissa sopeutumista on usein pyritty mittaamaan tai siihen liittyviä muuttujia on pyritty kartoittamaan ja rajaamaan. Vuorovaikutuksen näkökulma tarjoaa mahdollisuuden ymmärtää sopeutumisprosessia, ja tutkimukseen osallistuvilla on itsellään mahdollisuus määritellä, mikä heidän mielestään on sopeutumista tai millaisia tavoitteita ja toiveita heillä on elämälleen uudessa ympäristössä. Vuorovaikutuksen näkökulma sopeutumiseen, yhdessä puheviestinnän tutkimuksen ja teoreettisten huomioiden ja "keksintöjen" kanssa, voivat avata uuden näkökulman monikulttuurisen yhteiskunnan haastei- 
siin. Yhdessä vuorovaikutuksen näkökulma ja puheviestinnän tutkimus voivat auttaa hahmottamaan, ymmärtämään ja ratkaisemaan erilaisista kulttuurisista lähtökodista tulevien ihmisten vuorovaikutussuhteisin ja sopeutumiseen liittyviä haasteita ja ongelmia.

\section{KIRJALLISUUS}

Ahmad, A. 2005. Getting a job in Finland: the social networks of immigrants from the Indian subcontinent in the Helsinki metropolitan labour market. Research Reports No. 247. Helsinki: Helsingin yliopisto.

Alitolppa-Niitamo, A. 1994. Somalipakolaiset Helsingissä: Sosiaaliset verkostot ja klaanijäsenyyden merkitys. Helsinki: Sosiaali- ja terreysministeriö.

Altman, I. \& Taylor, D. A. 1973. Social penetration: 'The development of interpersonal relationships. New York: Holt, Rinehart \& Winston.

Arends-Tóth, J. \& van de Vijver, F. J. 2004. Domains and dimensions in acculturation: Implicit theories of Turkish-Dutch. International Journal of Intercultural Relations 28, 19-35.

Baxter, L. A. \& Montgomery, B. M. 1996. Relating: Dialogues and dialectics. New York: Guilford.

Baxter, L. A. \& Montgomery, B. M. 1997. Rethinking communication in personal relationships from a dialectical perspective. Teoksessa S. Duck (toim.) Handbook of personal relationships. Toinen painos. Chichester: John Wiley, $325-450$.

Berry, J. W. 1980. Acculuturation as varieties of adaptation. Teoksessa A. Padilla (toim.) Acculturation: Theory, models and some new findings. Boulder, CO: Westview, 9-25.

Berry, J. W. 1997. Immigration, acculturation, and adaptation. Applied Psychology: An International Review 46, 5-68.

Berry, J. \& Kim, U. 1987. Acculturation and mental health. Teoksessa J. Dasen, W. Berry \& N. Stratorius (toim.) Health and Cross-Cultural Psychology. Newbury Park, CA: Sage, 28-64.

Berry, J. W., Kim, U., Minde, T. \& Mok, D. 1987. Communication studies of acculturative stress. International Migration Review, 21, 491-511.

Berry, J. W., Kim, U., Power, S., Yound, M. \& Bujaki, M. 1989. Acculturation studies in plural societies. Applied psychology: An International Review 38, 135-186. 
Berry, J. W. \& Sam, D. 1997. Acculturation and adaptation. Teoksessa J. W. Berry, M. H. Segall \& C. Kagitcibasi (toim.) Handbook of cross-cultural psychology. Boston: Allyn \& Bacon, 291-326.

Billig, M., Condon, S., Edwards, D., Gane, M., Middelton, D. \& Radley, A. 1988. Ideological dilemmas. London: Sage.

Black, J. S. 1988. Work-role transition: A study of American expatriate managers in Japan. Journal of International Business Studies 19, 274-291.

Bourhis, R., Moïse, L., Perreault, S. \& Senécal, S. 1997. Towards an integrative acculturation model: A social psychological approach. International Journal of Psychology 32, 369-386.

Casmir, F. L. \& Asunción-Lande, N. 1990. Intercultural communication revisited: Conceptualization, paradigm building, and methodological approaches. Communication yearbook 12. Newbury Park, CA: Sage, 278-309.

Clément, R. \& Noels, K. A. 1992. Toward a situated approach to ethnolinquistic identity: The effects of status on individuals and groups. Journal of Language and Social Psychology 22, 203-232.

Cohen, Y. 1968. Man in adaptation. Chicago: Aldine.

Dobuzinskis, L. 1987. The self-organizing policy: An epistemological analysis of political life. Boulder, $\mathrm{CO}$ : Westview.

Dylan, J. \& Dylan, R. 1981. Acculturation, stress and coping. International Journal of Intercultural Relations 5, 301-328.

Eckenrode, J. \& Gore, S. 1981. Stressful events and social support: The significance on context. Teoksessa B. Gottlieb (toim.) Social networks and social support. Beverly Hills, CA: Sage, 43-68.

Ekholm, E. 1994. Syriäytyä vai selviytyä - pakolaisten elämää Suomessa. Sosiaali- ja terveysministeriön selvityksiä 1994: 9. Helsinki: Sosiaali- ja terveysministeriö.

Forsander, A. 2002. Luottamuksen ehdot. Maahanmuuttajat 1990-luvrun suomalaisilla työmarkkinoilla. Väestöntutkimuslaitoksen julkaisusarja D 39/2002. Helsinki: Väestöliitto.

Hagan, J. 1998. Social networks, gender, and immigrant incorporation: recourses and constraints. American Sociological Review 63, 55-67.

Hautaniemi, P. 2004. Pojat! Somalipoikien kiistanalainen nuoruus Suomessa. Nuorisotutkimusseuran julkaisuja 41. Helsinki: Nuorisotutkimusverkosto.

Hermans, H. J. \& Kempen, H. J. 1998. Moving cultures: the perilous problems of cultural dichotomies in a globalizing society. American Psychologist 53, 1111-1120.

Ho, T. \& Sung, K. 1990. Role of infrastructure networks in supporting social values 
to sustain economic success in newly-industrialized nations. International Journal of Psychology 25, 887-900.

Hurh, W. \& Kim, K. C. 1990. Adaptation stages and mental health of Korean male immigrants in the United States. International Migration Review 24, 456-479.

Huttunen, L. 2002. Kotona, maanpaossa, matkalla. Kodin merkitykset maahanmuuttajien omaelämänkerroissa. Helsinki: Suomalaisen kirjallisuuden seura.

Hyttinen, R. \& Tikkanen, A. 1997. The elderly ingrian remigrants in Helsinki. T'eoksessa M. Pitkäinen \& A. Jaakkola (toim.), Ingrians in municipalities. Helsinki: The Association of Finnish Local Authotities, 77-93.

Jantsch, E. 1980. The self-organizing universe: Scientific and human implications of the emerging paradigm of evolution. New York: Pergamon.

Jasinskaja-Lahti, I. \& Liebkind, K. 1997. Maahanmuuttajien sopeutuminen pääkaupunkiseudulla. Helsinki: Helsingin kaupungin tilastokeskus.

Jasinskaja-Lahti, I., Liebkind, K., Horenczyk, G. \& Shmitz, P. 2003. The interactive nature of acculturation: perceived discrimination, acculturation attitudes, and stress among young ethnic repatriates in Finland, Israel and Germany. International Joumal of Intercultural Relations 27, 79-97.

Kim, Y. Y. 2001. Becoming intercultural. An integrative theory of communication and cross-cultural adaptation. Thousand Oaks: Sage.

Kim, Y. Y., Lujan, P. \& Dixon, L. 1998. "I can walk both ways": Identity integration of American Indians in Oklahoma. Human Communication Research 25, $252-274$.

Kokkonen, L. 2006. Pakolaisten interpersonaaliset vuorovaikutussuhteet vieraassa maassa. Jyväskylän yliopisto. Viestintätieteiden laitos. Puheviestinnän lisensiaatintyö.

Knapp, M. L. \& Vangelisti, A. L. 1992. Interpersonal communication and human relationships. Boston: Allyn and Bacon.

Knudsen, J. C. 1988. Vietnamese survivors. Processes involved in refugee coping and adaptation. University of Bergen, Department of Social Anthropology.

Laroche, M., Kim, C., Hui, M. \& Joy, A. 1996. An empirical study of multidimensional ethnic change: The case of the French Canadians in Quebec. Journal of Cross-Cultural Psychology 27, 114-131.

Lazarus, R. 1966. Psychological stress and the coping process. St. Louis, MO: McGraw-Hill.

Lepola, O. 2002. Johdanto. Teoksessa O. Lepola (toim.), Koto-maana Suomi. Kertomuksia maahanmuutosta 1999-2001. Helsinki: Työministeriö ja Edita, $1-17$. 
Liebkind, K. 2000. Kun kulttuurit kohtaavat. Teoksessa Liebkind, K. (toim.), Monikulttuurinen Suomi, etniset suhteet tutkimuksen valossa. Helsinki: Gaudeamus, 13-27.

Luoma-aho, V. 2006. Luentomateriaalia kurssilta Multiculturalism and intercultural communication. Jyväskylän yliopisto, viestintäticteiden laitos, 24.11.2006.

Milroy, L. 1987. Language and social networks. Toinen painos. Oxford: Basil Blackwell.

Mortland, C. \& Ladgerwood, J. 1988. Refugee resource acquisition: The invisible communication system. Teoksessa Y. Y. Kim \& W. B. Gudykunst (toim.) Crosscultural adaptation: Current approaches. Newbury Park, CA: Sage, 286-306.

Nishida, H. 1985. Japanese intercultural communication competence and cross-cultural adjustment. International Journal of Intercultural Relations 9, 247-269.

Pehkonen, A. 2006. Maahanmuuttajan kotikunta. Helsinki: Kunnallisalan kehittämissäätiö.

Phinney, J. 1993. Multiple group identities: Differentiation, conflict, and integration. Teoksessa J. Ktoger (toim.) Discussions on ego identity. Hillsdale, NJ: Lawrence Entlbaum, 47-74.

Piaget, J. 1963. The origins of intelligence in children. New York: W.W. Norton.

Pohjanpää, K. 2003. Sosiaaliset suhteet. Teoksessa K. Pohjanpää, S. Paananen \& M. Nieminen (toim.) Maahanmuuttajien elinolot. Venäläisten, virolaisten, somalialaisten ja vietnamilaisten elämää Suomessa 2002. Helsinki: Tilastokeskus, 128-136.

Pohjanpää, K., Paananen, S. \& Nieminen, M. 2003. Maahanmuuttajien elinolot. Venäläisten, virolaisten, somalialaisten ja vietnamilaisten elämää Suomessa 2002. Helsinki: Tilastokeskus.

Redfield, R., Linton, R. \& Herskovits, M. 1936. Memorandum on the study of acculturation. American Anthropologist 38, 149-152.

Rogers, E. M. \& Kincaid, D. L. 1981. Communication networks. Toward a new paradigm for research. New York: Free Press.

Rogers, L. E. 1998. The meaning of relationships in relational communication. Teoksessa R. L. Conville \& L. E. Rogets (toim.), The meaning of "relationship" in interpersonal communication. Westport, Connecticut: Praeger, 69-82.

Rogler, L. J., Cortes, D. E. \& Malgady, R. G. 1991. Acculturation and psychological functioning status among Hispanic: Convergence and new directions for research. American Psychologist 46, 585-597.

Rommakkaniemi, H. 1997. Ingrian remigrant youth in the capital city Helsinki. Teoksessa M. Pitkänen \& A. Jaakkola (toim.), Ingrians in municipalities. The association of Finnish local authorities, 64-76. 
Salminen, O. 1997. Entisestä Jugoslaviasta tulleiden pakolaisten kotoutuminen. Sosiaali- ja terveysministeriön selvityksiä 1997:9. Helsinki: Sosiaali- ja terveysministeriö.

Searle, W. \& Ward, C. 1990. The prediction of psychological and sociocultural adjustment during cross cultural transitions. International Journal of Intercultural Relations 14, 449--464.

Sigman, S. J. 1998. Relationships and communication: A social communication and strongly consequential view. Teoksessa R. L. Conville \& L. E. Rogers (toim.), The meaning of "telationship" in interpersonal communication. Westport, Connecticut: Praeger, 41-82.

Sourander, A. 2003. Refugee families during asylum seeking. Nordic Journal of Psychiatry 57, 203-207.

Triandis, H. C. 1997. Where is culture in the acculturation model? Commentary on "Immigration, acculturation, and adaptation" by John W. Berry. Applied Psychology: An International Review 46, 55-58.

Valtonen, K. 1994. The adaptation of Vietnamese refugees in Finland. Journal of Refugee Studies 7, 63-78.

Valtonen, K. 1998. Resettlement of Middle Eastern refugees in Finland: The elusiveness of integration. Joutnal of Refugee Studies 11, 38-60.

van Oudenhoven, J. \& Eisses, A. 1998. Integration and assimilation of Moroccan immigrants in Israel and the Netherlands. International Journal of Intercultural Relations 22, 293-307.

Ward, C. 1996. Acculturation. Teoksessa D. Landis \& R. Bhagat (toim.), Handbook of intercultural training. Toinen painos. Thousand Oaks, CA: Sage, 124-147.

Ward, C. 1997. Culture learning, acculturative stress and psychopathology: Three perspectives on acculturation. Applied Psychology: An International Review 46, 58-62.

Ward, C., Bochner, S. \& Furnham, A. 2001. The psychology of culture shock. Toinen painos. Hove: Routledge.

Ward, C. \& Kennedy, A. 1992. Locus of control, mood disturbance, and social difficulty during cross-cultural transition. International Journal of Intercultural Relations 16, 175-194.

Ward, C., Okura, Y., Kennedy, A. \& Kojima, T. 1998. The U-curve on trial: A longitudinal study of psychological and sociocultural adjustment during crosscultural transition. International Journal of Intercultural Relations 22, 277-291.

Ward, C. \& Searle, W. 1991. The impact of value discrepancies and cultural identity on psychological and sociocultural adjustment of sojourners. International Journal of Intercultural Relations 15, 209-225. 